\title{
SATISFACTION OF Cu AND Zn REQUIREMENTS OF DARIY COWS FED DIFFERENT RATIONS IN WINTER TEME NUTRITION
}

Senada Cengic

University of Sarajevo, Faculty of Agriculture, Bosnia and Herzegovina

\section{SUMMARY}

An experiment was carried out to study $\mathrm{Cu}$ and $\mathrm{Zn}$ nutrition of dairy cows fed different winter-type rations. The rations consisted of typical lorage and concentralce fecds (maize silage. meadow hay brewers grain, sunflower meal, sugar beet pulp and concentrate mixlure), all without mineral supplement. The $\mathrm{Cu}$ concentrations were $12.50 \mathrm{ppm}$ (ration A); $13.73 \mathrm{ppm}$ (ration B); $12.28 \mathrm{ppm}$ (ration $\mathrm{C}$ ); and $14.04 \mathrm{ppm}$ (ration D); and $\mathrm{Zn}$ concentrations were $67,56 \mathrm{ppm} ; 70.26 \mathrm{ppm} ; 58.97 \mathrm{ppm}$ and 70.13. ppm in rations $A, B, C$, and $D$, respectively. All rations had higher concentrations of $\mathrm{Cu}$ and $\mathrm{Zn}_{\mathrm{n}}$, as compared to INRA (88) recommendations. The content of trace elements in milk of tested cows were $1.15 \mathrm{ppm}$ and $4.11 \mathrm{ppm}(\mathrm{A}) ; 0.89 \mathrm{ppm}$ and $3.40 \mathrm{ppm}(\mathrm{B}) ; 0.36 \mathrm{ppm}$ and $3.25 \mathrm{ppm}$ (C); $1.38 \mathrm{ppm}$ and $3.86 \mathrm{ppm}(\mathrm{D})$ for $\mathrm{Cu}$ and $\mathrm{Zn}$ content, respectively, and there were no statistically significant differences between treatments for trace elements.

The difference of $\mathrm{Cu}$ balance in treatment $\mathrm{D}(10.06 \mathrm{mg} /$ day $)$ were significantly higher compared to other treaments (3.00 $\mathrm{mg}-\mathrm{A} ; 4.96 \mathrm{mg}-\mathrm{B}$ and $5.47 \mathrm{mg}-\mathrm{C}$ )

The mean value of daily $\mathrm{Zn}$ balance $(43.34 \mathrm{mg}-\mathrm{A} ; 26.44 \mathrm{mg}-\mathrm{B} ; 16.90 \mathrm{mg}-\mathrm{C}$; and $40.91 \mathrm{mg}-\mathrm{D})$ were not statistically significant between treatments $(P=0,531)$.

Keywords: Copper, zinc, dairy cows, balance

\section{INTRODUCTION}

$\therefore$ All forms of living miatter require inorganic elements, or minerals, for their normal life processes. Mineral elements exist in the cells and tissue of the animal body in a variety of functional chemical combinations and in specific concentrations : which vary with the element and the tissue. The concentrations must be maintained within quite narrow limits, or normal ranges, if the functional and structural integrity of the tissues is to be safeguarded and the growth, health and productivity of the animal are to remain unimpaired: The main three types of trace minerals function found in animal body are structural, electrolytic and enzymatic. Large numbers of livestock in many parts of the world consume diets that do not meet these mineral requirements. As a consequence, nutritional disorders arise which range from acute or severe mineral deficiency or toxicity disease to mild and transient conditions difficult to diagnose with certainty; and are expressed: merely as unsatisfactory growth, production and fertility. Mild or marginal deficiencies or toxicities of this nature are of great importance in the nutrition of livestock because of their extent and the ease with which they can be confused with the effects of semistarvation due to underfeeding, protein deficiency and various types of parasitic infestation.

The aim of the study is : to investigate $\mathrm{Cu}$ and $\mathrm{Zn}$ content in various feedstuffs used in dairy cows' nutrition during winter time. Additionally, the aim is to investigate apparent availability of those minerals obtained from different winter time rations.

\section{MATERIALS AND METHODS}

Expèrimental animals and procedure

Sixteen Holstein cows with body weight $610 \pm 22 \mathrm{~kg}$, age $46 \pm 3.5$ months and producing $14.20 \pm 0.45$ $\mathrm{kg}$ milk, divided into four groups are used in the study with the aim to investigate $\mathrm{Cu}$ and $\mathrm{Zn}$ balances. The balances are estimated as differences between the amount of minerals consumed and their aniounts in detected feces, urine and milk.

The experiment consisted of a preparation phase (21 days) and a collecting phase ( 7 days): 
Experimental rations

Each group were fed with differing rations consisting of typically used feecistuffs in winter time dairy cows' diet (Table 1).

Table 1. The ingredient and nutrient composition of experimental rations*

\begin{tabular}{|c|c|c|c|c|c|c|c|}
\hline \multicolumn{4}{|l|}{. } & \multicolumn{4}{|c|}{ Rations } \\
\hline-7 & & & & $\mathbf{A}$ & $\mathbf{B}$ & C & $\mathbf{D}$ \\
\hline Ingredient & & & & & & & \\
\hline Corn silage. $\%$ & & & & 46016 & 49.5 & 52.81 & 45.37 \\
\hline Nalural grass hay, \% & & & & 1.91 & 12.71 & 13.61 & 5.89 \\
\hline Brewer's grain, \% & & & & 12.79 & 6.82 & $\therefore$ &. \\
\hline Sunflower solvent extracte & d with & hulls, & $\%$ & " & 6.32 & 13.55 & 8.73 \\
\hline Sugar beet pulp, \% & & & & $\because$ & $\therefore$ & - & 11.38 \\
\hline Concentrate mixture, $\%$ & & . ' & $\therefore$ & $29: 14$ & 24.91 & 20.02 & 28.64 \\
\hline Nutrient composition & & & & & & & \\
\hline - Dry matter, \% & & & & 31.62 & 33.17 & 35.11 & 38.28 \\
\hline - Crude fiber, \% & & & & 20.08 & 21.72 & 23.62 & 20.11 \\
\hline - Crude protein, \% & & & & 11.88 & 12.12 & 12.40 & 11.55 \\
\hline $\mathrm{GE}, \mathrm{MJ}$ & & & & 18.32 & 18.25 & 18,17 & 18.02 \\
\hline $\mathrm{ME}, \mathrm{MJ}$ & & & & 10.92 & 10.88 & 10.79 & 10.76 \\
\hline q factor & & & & 0.596 & 0.596 & 0.594 & 0.597 \\
\hline NEL, MJ & & & . & 6.62 & 6.60 & 6.54 & 6.53 \\
\hline NEGF, MJ & & . & & 6.71 & 6.69 & 6.62 & 6.62 \\
\hline
\end{tabular}

Sampling procedures and analytical methods

Feed, milk, feces and urine samples were taken daily during collecting phase and preserved.

Dry inatter, crude fiber and crude protein were determined to be present in the samples, according to

Weende procedure. GE, ME, NEL and NEGF were estimated according to I NR A (1989) equations The samples preparation and $\mathrm{Cu}$ and $\mathrm{Zn}$ determination in feed, feces, urine and milk were assessed according to A 0 A C (1980) using Atomic Absorption Spectrophotometry (AAS)

Samples of feeds and faeces were prepared with a dry asling procedure. Samples of $t$ e urine were prepared consequent to evaporation. Samples were heated at $550^{\prime \prime} \mathrm{C}$ for 81012 hours then $10 \mathrm{ml}$ of $6 \mathrm{M}$ $\mathrm{HCl}$ was added After the samples were boiled under controlled heat. filtrated through aslless fitter paper and filled by ydestilled water to $100 \mathrm{ml}, \mathrm{Cu}$ and $\mathrm{Zn}$, contents were read direcfly from digested volume to the AAS.

\section{Statistical analysis}

Statistical levels of the samples were tested using the ANOVA (S A 5, 1988) procedure, using "Statistic for Windows" - Stat. Soft:, Inc. (1993).

\section{RESULTSAND DISCUSSION}

The $\mathrm{Cu}$ and $\mathrm{Zn}$ content in the investigated feedstuffs and experimental rations

The content of the investigated trace elements in sampled feedstuffs are shown in Table 2

Table 2. Copper and Zinc content in investigated feedstuffs*

\begin{tabular}{lcc}
\hline Feedstuffs & $\mathrm{Cu}, \mathrm{ppin}$ & $\mathrm{Zn}, \mathrm{ppm}$ \\
\hline Cont silage & 3.59 & 24.15 \\
NaturaI grass hay & 5.53 & 34.61 \\
Brewer's grain & 12.11 & 25.47 \\
Sunflower solvent extracted with hulls & 33.97 & 89.62 \\
Sugar beet pulp & 5.63 & 10.19 \\
Concentrate mixture & 29.61 & 168.17 \\
\hline " All values are expressed on dry matter basis & &
\end{tabular}

The variability of $\mathrm{Cu}$ and $\mathrm{Zn}$ content in forage is more wider compared to their contents in concentrates (McDwell, 1992). The different parts of dry matter from forage influenced on different concentrations of $\mathrm{Cu}$ and $\mathrm{Zn}$ in investigated rations (Table 3 ). 
Table 3. Cupper and zinc content in investigated rations

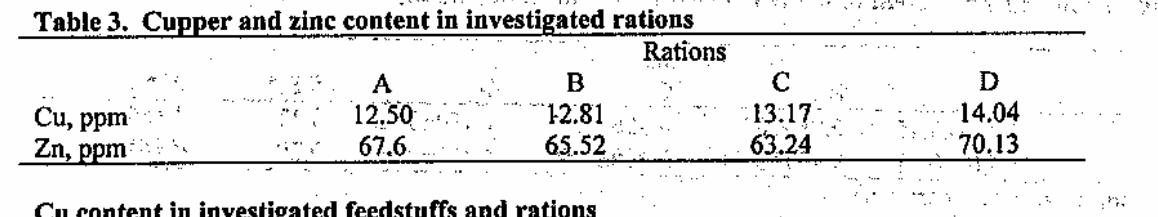

Cu content in investigated feedstuffs and rations

Concentrations of copper in crops and forages are dependent on plant species, soil factors, stage of maturity, crop management, yield and climate (McDowe 11, 1992). Nutrition with these trace elements is complicated by the presence of other minerals (especially $\mathrm{Mo}$ and $\mathrm{S}$ ) which strongly influence copper availability (Baker, 1995). Great variability of $\mathrm{Cu}$ content in forage has been by many ant ors as a result of the influence from the above mentioned factors. Investigated corn silage contained $3.59 \mathrm{ppm}$ and natural grass hay contained $5.53 \mathrm{ppm}$ of $\mathrm{Cu}$. These results corresponded with the values reported by INRA (1989), McDona1d (1995) and Paragon (1995). Cu concentrations in forage can not satisfy demand of dairy cows. Coic and Coppenet (1989) reported that average concentration of $\mathrm{Cu}$ in corn silage and natural grass hay was $4.5 \mathrm{ppm}$ and dairy cows requirements are $10 \mathrm{ppm}$ of $\mathrm{Cu}$. Cu content in investigated brewer's grain (12.11 ppm) was below values reported by Paragon (1995) and McDonald (1995) which ranged from 25 to $70 \mathrm{ppm}$ of Cu. Concentrations of $\mathrm{Cu}$ in used sugar beet pulp (5.63 $\mathrm{ppm})$ and sunflower solvent extracted with hulls $(3.97 \mathrm{ppm})$ corresponded with known literature values.

Because of small range between minimal requirement and toxicity levels of $\mathrm{Cu}$ in ruminant rations (this range is from 7 to $30 \mathrm{ppm}$, according INRA, 1989), property nutrition of ruminants with these minerals is very sensitive. The sample rations contained from 12,50 to $14,04 \mathrm{ppm}$ of $\mathrm{Cu}$. This content was higher than published recommendations (NRC, 1984; INRA, 1988; ARC, 1980 and Grace, 1989), but was closest to recommended values published in (ARC, 1980).

Crops are richer in Cu content than forage The highest level of concentrates as a percentage of total dry matter were found in ration $\mathrm{D}(48.74 \%)$ which elevated the level of $\mathrm{Cu}$ content in this ration $(14.04$ $\mathrm{ppm})$. The smallest concentration of $\mathrm{Cu}$ is in ration $\mathrm{A}(12.50 \mathrm{ppm})$, and was due to the absence of sunflower solvent extracted with hulls which naturally is rich in copper.

\section{Zn content in investigated feedstuffs and rations}

Investigated com silage contained $24,15 \mathrm{ppm} \mathrm{Zn}$, natural grass hay $34,61 \mathrm{ppm}$, brewer's grain 25,47 ppm, sunflower solvent extracted with hulls $89.62 \mathrm{ppm}$, sugar beet pulp 10,91 ppm and concentrate mixture $168,17 \mathrm{ppm} \mathrm{Zn}$. Values of $\mathrm{Zn}$ content in corn silage reported by NRC (1989), Miller, (1979), I NRA (1989), and McDonald (1995) corresponded with the $\mathrm{Zn}$ content in investigated corn silage while tested natural grass hay was slightly-richer in $\mathrm{Zn}$ content. Among other factors, content of zinc in hay depend on their concentrations in soils (Lamand, 1989). as well as of botanical structure of hays. INRA (1989), McDonald et al.(1995) and NRC (1989) reported that sugarbeet pulp contained $9.6 \mathrm{ppm}, 11$. $\mathrm{ppm}$ and $14 \mathrm{ppm}$ of $\mathrm{Zn}$ respectively and concentration of $\mathrm{Zn}$ in brewers grain ranged from $25 \mathrm{ppm}$ (McDonald et al., 1995) to $80 \mathrm{ppm} \mathrm{Zn} \mathrm{(NRC,1989).} \mathrm{These} \mathrm{values} \mathrm{corresponded} \mathrm{with} \mathrm{concentrations} \mathrm{of}$ Zinc in investigated brewer's grain and sugarbeet pulp.

Zinc concentration in plant protein sources is higher than in forages. Investigated sunflower solvent extracted with hulls contained $89 \sim 62 \mathrm{ppm}$ of $\mathrm{Zn}$. These values corresponded with known literature values (I NRA, 1989 and NRC, 1989).

Zinc deficiency in ruminarits often passes unnoticed. The deficiency is more characteristic in young animals whereas in adult the symptoms are rarely obvious. Deficiency due to low dietary zinc or primary deficiency is rare but secondary deficiency arising from modification of zinc digestibility is more frequent (Laman (1989). Optimal concentrations of Zine in dairy cow rations ranged from 25 to 50 ppm NRC, 1984; INRA, 1988; A R C, 1980). Toxicity levels are also different and ranged from 250 ppm of $\mathrm{Zn}$ (INRA, 1988) to $2000 \mathrm{ppm}$ (Miller el al., 1979). The concentrations $\mathrm{Zn}$ were similar in all tested rations except ration $\mathrm{C}$ which had lower $\mathrm{Zn}$.

This fact is explained by higher concetration of forage in total dry matter of ration. It is known that forage is poorer in $\mathrm{Zn}$ content than concentrates. All experimental rations contained higher concentrations of Zin than optimal requirements but below toxic levels.

Cu and $\mathrm{Zn}$ content in milk of the experimental animals

The mineral composition of tillk varies with the animal species, the stage of lactation and the nutrition of the lactating animal (Underwood, 1981). Cow's milk contains 7-8 gash where Ca and $P$ are most representative while trace mineral content is relatively low.

The concentrations of $\mathrm{Cu}$ and $\mathrm{Zn}$ in milk of experimental animals are given in the Table 4. 
Table 4. $\mathrm{Cu}$ and $\mathrm{Zn}$ content in the milk of experimental cows, $\mathrm{mg} / \mathrm{kg}$

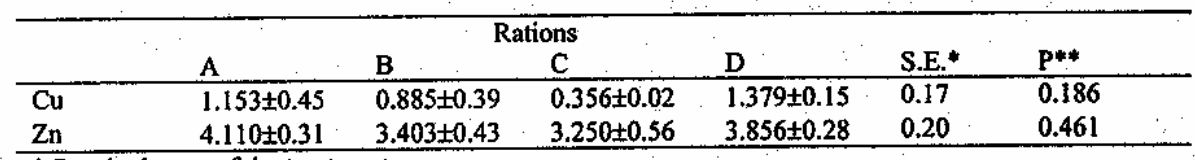

* Standard error of the treatments

** level of significance

Milk and milk products are poor in copper content but during processing and storage $\mathrm{Cu}$ content can significantly increase due to contamination with metals (McDowell, 1992). Normal Cu content in cow's milk ranges from 0.02 to $0.2 \mathrm{mg} / \mathrm{l}$ (INRA, 1988) and it is not dependent on dietary Cu content (Paragon, 1998). Concentrations of copper in milk of experimental animals widely varied among differen treatments (from $0.356 \mathrm{mg} / \mathrm{kg}$ in treatment $\mathrm{C}$ to $1.379 \mathrm{mg} / \mathrm{kg}$ in treatment $\mathrm{D}$ ) as well as among animals in each treatment. Differences in $\mathrm{Cu}$ content in milk of animals among various treatments are not statistically significant $(\mathrm{P}=0.186)$. Cu content in milk of animals of each treatment were above known literature values (INRA,1988;Grace, 1989; Anderson, 1992).

According to many authors normal $\mathrm{Zn}$ content in cow's milk ranges from 3 to $5 \mathrm{mg} / \mathrm{kg}$ of milk. There exists a strong correlation between $\mathrm{Zn}$ content in milk and in ration ( $\mathrm{p}$ a r a g o $\mathrm{n}, 1998$ ). High $\mathrm{Zn}$ content in ration increases $\mathrm{Zn}$ content in milk, but further increasing $\mathrm{Zn}$ in diet has little effect. Because of almost same concentrations of $\mathrm{Zn}$ in experimental rations, differences in $\mathrm{Zn}$ content in milk among different treatments were not statistically significant $(\mathrm{P}=0.461)$. $\mathrm{Zn}$ contents in milk of sampled animals (from $3,250 \mathrm{mg} / \mathrm{kg}$ in treatment $\mathrm{C}$ to $4,110 \mathrm{mg} / \mathrm{kg}$ in treatment $\mathrm{A}$ ) corresponded with published values reported by INRA (1988), Grace(1989), Anderson(1992) and Underwood (1981).

Balance of $\mathrm{Zn}$ and $\mathrm{Cu}$

Average daily balance of investigated trace elements age given in the following table.

Table $5 . \mathrm{Zn}$ and $\mathrm{Cu}$ balance

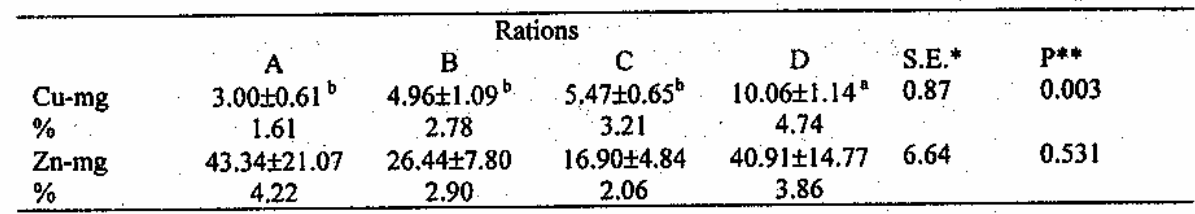

$a, b$ Means in the same rows with different letters in their superscripts differ $\sim 0,05$ )

Most of feedstuffs, especially concentrates, contain high concentrations of $\mathrm{Cu}$, despite the fact that $\mathrm{Cu}$ deficiency in animal nutrition is very often due to different interactions between $\mathrm{Cu}$ and other minerals. As a consequence, this demonstrates very low levels of $\mathrm{Cu}$ retention. Generally, absorption of $\mathrm{Cu}$ is not more than $5-10 \%$ in adult animals, while young animals' may absorb $15-30 \%$ of $\mathrm{Cu}$ McDowell, 1992). The average $\mathrm{Cu}$ balance of all experimental rations were positive and ranged from $3.00 \mathrm{mg}$ (ration A) to $10.06 \mathrm{mg}$ (ration D).

The mean value of $\mathrm{Cu}$ balance in ration $\mathrm{D}$ is higher $\mathrm{P}=0.003$ ) compared to other rations. Copper deficiency is a serious problem for grazing ruminants in many countries of the world. This is due both to low concentrations of $\mathrm{Cu}$ in forage as well as to elevated amounts of $\mathrm{Mo}$ and $\mathrm{S}$, which interfere with copper utilization (Baker, 1995). This fact explains a higher balance of $\mathrm{Cu}$ in ration $\mathrm{D}$ because of the lower concentration of forage in total dry matter of that ration.

The average $\mathrm{Zn}$ balance of all experimental rations were positive and ranged from $16-90 \mathrm{mg}$ (ration C) to $43.34 \mathrm{mg}$ (ration A) with strong variations among animals $(S . E .=6,64)$ so differences among different treatments were not statistically significant $(\mathrm{P}=0.531)$. The most important factor affecting absorption is $\mathrm{Zn}$ content of the diet. With high $\mathrm{Zn}$ in diet, there is a reduction in the percentage absorbed (sometimes to less than $10 \%$ ). Dairy cattle compensated for low $\mathrm{Zn}$ in diets by increasing absorption, a decrease in milk $\mathrm{Zn}$, and a decline in excretion of $\mathrm{Zn}$ in feces (McDowe11, 1992). This fact explains high levels of $\mathrm{Zn}$ in experimental rations and relatively low balance of $\mathrm{Zn}$ of each treatments. 


\section{CONCLUSIONS}

On the basis of investigation the following conclusions can be drawn:

1. $\mathrm{Cu}$ and $\mathrm{Zn}$ content in investigated feedstuffs ranged according to published values. $\mathrm{Cu}$ and $\mathrm{Zn}$ content in forage as well as in sugar beet pulp could not satisfy dairy cow's demands. The concentrations of $\mathrm{Cu}$ and $\mathrm{Zn}$ in other feedstuffs (brewer's grain. sunflower solvent extracted with hulls and concentrate mixture) were above recommendations for dairy cows.

2. $\mathrm{Zn}$ and $\mathrm{Cu}$ content in the examined rations were above recommendations (NRC. 1984: INRA. 1988; ARC, 1980 and Grace, 1989) but below toxic levels.

3. Although there exists a correlation between $\mathrm{Cu}$ and $\mathrm{Zn}$ content in milk and its content in ration, the mean values of their content in milk of tested animals were not statistically significant.

4. Copper and Zinc balance were counted as a difference between their amount in rations and their amount in feces, milk and urine.

The average $\mathrm{Cu}$ balance of all experimental rations were positive and ranged from $3.00 \mathrm{mg}$ (ration A) to $10.06 \mathrm{mg}$ (ration $\mathrm{D}$ ). The mean value of $\mathrm{Cu}$ balance in ration $\mathrm{D}$ is higher $(\mathrm{P}=0.003)$ compared to other rations.

The average $\mathrm{Zn}$ balances of all expcrimental rations were positive and ranged from $16.90 \mathrm{mg}$ (ration C) to $\mathrm{mg}$ (ration $\mathrm{A}$ ) with strong variations among animals ( $\mathrm{S} . \mathrm{E}=6.64$ ) so differences among different treatments were not statistically significant.

\section{REFERENCES}

Anderson, R.R., 1992. Comparasion of trace elements in milk of four species. Joumal of Dairy Science, $75: 3050-3055$.

AOAC (Association of Official Analytical Chemists), 1980. Official Methods of Analysis. 15th ed, AOAC., Arlington, Virginia, USA.

ARC., 1980. Agricultural Research Council. The Nutrient Requirements of Ruminant Livestock. Farnham Royal, Slough: Commonwealth Agricultural Bureaux.

Baker, H.D., 1995. Zinc Bioavailability. In Bioavailability of Nutrients for Auimals (Anino Acids. minerals and Vitamins). Academic Press, INC. San Diego, California.

Coic, Y, and M. Coppenet, 1989. Les oligo - elements en agriculture et elevage. INRA,Paris, France,

GRACE, N. D., 1989. Trace minerals requirements of ruminants. Proceedings of the International Meeting on Mineral Nutrition and Mineral Requirements in Ruminants. Kyoto, Japan.

INRA. 1988. Alimentation des bovins, ovins et caprins. 4eme edition, INRA, Paris. France.

INRA. 1989. Ruminant Nutrition, Recommended Allowances and Feed Tables. Paris, France.

LAMAND, M., 1989. Zinc deficiency in ruminants. Proceedings of the International Meeting on Mineral Nutrition and Mineral Requirements in Ruminants. Kyoto, Japan.

McDonald P., Edwards R.A., Greenlualgh, J.F.D., and Morgan, C.A., 1995. Animal Nutrition. 5th Ed, Longman, United Kingdom.

McDowell, L.R., 1992. Minerals in Animal and Human Nutrition. Academic Press. Inc. USA.

Miller, W.J., 1979. Dairy Cattle Feeding and Nutrition. Academic Press. New York.

Mwler, E.R., Stowe, H.D., KU, P.K. and HILL. G.M., 1979. Copper and Zinc in Animal Nutrition. Literature Review Committee, National Feed Ingredients Association, West Des Moines, Iowa.

NRC. 1984. National Research Council: Nutrient Requirements of Domestic Animals. Washington, D.C. USA.

NRC, 1989. National Research Council: Nutrient Requirements of Domestic Animals, Nutrient Requirements of Dairy Cattle. 6rd Ed. National Academy of Sciences, Washington, D.C. USA.

Paragon, B.M., 1995. Sel, Mine raux Aliments des Ruminants, Compagnie des Salins du Midi et des Salines de l' Est., France.

Paragon, B.M., 1998. CSAAD, Alimentation minerale: Oligo - elements et nutrition minerale des animaux domestiques. INA - Paris Grignon, France.

Statistical Analysis Systems Institute, 1988. SASISTAT user's guide, release 6.03 edition. Statistical analysis systems institute Inc., Cary. NC.

Statistica For Windows, 1993. Stat soft., Inc. Charles University, Prague.

Underwood, J.E., 1981. The Mineral Nutrition of Livestock. CAB, England 